\title{
Voluntary intake, digestion, rate of passage, amount of material in the alimentary tract and behaviour in cows receiving complete diets containing straw and concentrates in different proportions
}

\author{
By J. A. BINES AND A. W. F. DAVEY* \\ National Institute for Research in Dairying, Shinfield, Reading $R G{ }_{2} A T$
}

(Received 9 February 1970-Accepted 24 fune 1970)

\begin{abstract}
I. Pelleted diets containing concentrates and o, 20, 40 or $60 \%$ chopped straw were fed ad lib. for $5 \mathrm{~h}$ daily to four cows. Voluntary intake, digestion and rate of passage of these diets were examined, and also the behaviour of the cows and the amount of material in the rumen before and after feeding.

2. Least dry matter $(7.5 \mathrm{~kg})$ was consumed when there was no roughage in the diet. When roughage was present, its level had no effect on dry-matter intakes, which were $10 \cdot 7,11 \cdot 3$ and $10.7 \mathrm{~kg}$ for 20,40 and $60 \%$ roughage respectively. Digestible energy intakes were greatest with diets containing 20 or $40 \%$ roughage.

3. The digestibilities of the dry matter of the four diets were $81,69,59$ and $55 \%$ in increasing order of roughage content. The proportion of total digestion which occurred in the rumen decreased as the roughage content of the ration increased. The rate of breakdown of cotton threads in the rumen increased as the roughage content of the diet increased.

4. Rates of passage varied greatly between cows and there were no differences between treatments in passage rates through the entire alimentary tract. The diets on which the cows consumed the largest amounts of digestible energy ( 20 and $40 \%$ roughage) passed through the rumen more slowly, and through the hind gut more quickly, than the other diets.

5. The times spent daily eating and ruminating both increased as the proportion of roughage in the diet was increased, but in relation to the amount of dry matter eaten, eating times were lowest with diets containing 20 or $40 \%$ roughage. Time spent ruminating per kg straw eaten decreased with increasing straw content of the diet. Rumen contraction rate during eating was greatest when dry-matter intake was greatest, but during rumination it was similar with all three levels of roughage.

6. Before and after feeding, the amount of digesta and digesta dry matter in the rumen increased as the proportion of roughage in the diet increased. After feeding, there was a highly significant linear relationship between the amount of digesta in the rumen and the digestibility of the diet.

7. In a second experiment, similar diets containing 0 or $50 \%$ roughage were given to two cows for 5 or $24 \mathrm{~h}$ daily. The $24 \mathrm{~h}$ intake expressed as a percentage of $5 \mathrm{~h}$ intake was $148 \%$ for the $0 \%$ roughage diet, but only $105 \%$ when the diet contained $50 \%$ roughage.

8. The results of these experiments are interpreted as indicating a declining importance of physical factors in the regulation of the intake by cows of a range of diets of increasing digestibility.
\end{abstract}

There is a need to investigate further the factors that regulate voluntary intake in ruminants so that intake can be predicted over a wide range of food and, on occasions, increased consumption can be obtained. This knowledge would lead to the more efficient production of milk and meat.

Many workers (e.g. Balch \& Campling, 1962; Blaxter, Wainman \& Wilson, 1961) have concluded that, when roughages are eaten, physical distension of the reticulorumen is an important factor regulating food intake in ruminants. The results obtained by Ulyatt, Blaxter \& McDonald (1967) support the hypothesis that sheep voluntarily

* Present address: Massey University, Palmerston North, New Zealand. 
consume roughages of different qualities to achieve constant fill of the rumen. Blaxter (1950-I) made the generalization that the amount of food dry matter consumed increased with increasing concentration of the ration expressed as net energy per unit of dry matter.

In contrast, from the results of experiments in which diets containing different proportions of lucerne and maize were given to heifers and lambs, Montgomery \& Baumgardt (1965) concluded that ruminants will adjust voluntary food intake in relation to the physiological demand for energy if fill or rumen load does not limit their consumption. According to their views, energy intake would be expected to rise with increasing nutritive value of the diet, becoming constant at a level which met the animal's physiological demand for energy. Once this level was reached, the intake of dry matter would decline as the nutritive value of the diet was further increased in order to maintain a constant energy intake. This theory implies that, with diets of high nutrient value, intake would be regulated by chemostatic or thermostatic mechanisms.

In our study physical and chemical changes associated with food intake have been examined simultaneously. Diets with a wide range of digestibility were used and physical changes, such as the amount of material in different parts of the gut and rate of passage of food residues, were measured as well as changes in the levels of various metabolites in the rumen and blood. It was considered necessary to cover digestibilities from 55 to $80 \%$, as this range includes the digestibilities of most diets for dairy cows in this country. This was achieved by preparing four diets containing different proportions of straw and concentrate; the diets were pelleted to prevent selection of individual components by the cows. The use of straw rather than hay permitted a reduction in the range of roughage: concentrate ratios required, thus facilitating quick changes from one diet to another during the experiment. It was considered important to use chopped rather than ground straw and to include in the measurements an assessment of the possible contribution of fill in the intestine to the control of intake of the complete diets. Distension of the intestine has been implicated (Campling \& Freer, 1966) in the regulation of intake of ground roughages, although this is not thought to be of any importance in the control of concentrate intake (Freer \& Campling, 1963). This paper deals with the physical measurements; concentrations of energy-yielding metabolites in the rumen and in blood will be dealt with subsequently.

\section{EXPERIMENTAL}

\section{Expt I : procedure}

A balanced $4 \times 4$ Latin square experiment was used to compare the following diets each given to four cows:

$\begin{array}{ccc}\text { Diet } & \begin{array}{c}\text { Barley straw } \\ (\%)\end{array} & \begin{array}{c}\text { Concentrate } \\ (\%)\end{array} \\ 60 \mathrm{R} & 60 & 40 \\ 40 \mathrm{R} & 40 & 60 \\ 20 \mathrm{R} & 20 & 80 \\ \text { oR } & 0 & 100\end{array}$


Each 5-week experimental period consisted of: $14 \mathrm{~d}$ for adjustment to the diet; ro $d$ during which voluntary food intake, digestibility in the reticulo-rumen and in the entire digestive tract, breakdown of cotton threads in the ventral sac of the rumen, and mean retention time of undigested feed residues in the hind gut and in the entire digestive tract were measured; $3 \mathrm{~d}$ during which blood and rumen samples were collected (the results obtained from these samples will be the subject of another paper); $3 \mathrm{~d}$ recovery; $3 \mathrm{~d}$ on which behaviour was recorded; $2 \mathrm{~d}$ on which the amount of material in the reticulo-rumen was measured and the cows were weighed, after feeding but with the rumen emptied.

\section{Cows and housing}

The cows were mature non-pregnant, non-lactating Friesians, each fitted with a permanent rumen fistula closed by a rubber cannula and bung. The cows were housed in individual standings in a metabolism house. Water and salt licks containing trace elements were available at all times. During the experiment, the mean live weight of the cows, with the rumen emptied, was $532 \mathrm{~kg}$.

\section{Foods}

The barley straw was chopped to give particles with a mean length of $\mathrm{I} .09 \pm 0.021 \mathrm{~cm}$. Particle length was determined by separating the straw content of the extruded complete diets by flotation in water. The straw particles were air-dried, mixed

Table I. Expt I. Composition of the complete diets given to the cows

\section{Component}

Chopped barley straw
Concentrate
Molasses
Sodium chloride
Dicalcium phosphate

DM $(\%)$

$\left.\begin{array}{l}\text { Organic matter } \\ \text { Crude protein } \\ \text { Ether extract } \\ \text { Celluloset } \\ \text { Lignin } \\ \text { Ash }\end{array}\right\}$ as \% of DM

Calorific value (kcal/g DM) $\ddagger$

Diet
$60 R$
60
27
10
$1 \cdot 5$
$1 \cdot 5$

$86 \cdot 56$ $92 \cdot 50$

$9 \cdot 15$

$1 \cdot 92$

$32 \cdot 47$

$5 \cdot 72$

$7 \cdot 50$

$4 \cdot 35$

Propo

Diet

$4 \circ \mathrm{R}$

Diet

$20 \mathrm{R}$

Diet $\circ \mathbf{R}$

Proportions* (\% by weight)

$\begin{array}{ccc}40 & 20 & 0 \\ 47 & 67 & 87 \\ 10 & 10 & 10 \\ 1 \cdot 5 & 1 \cdot 5 & 1 \cdot 5 \\ 1 \cdot 5 & 1 \cdot 5 & 1 \cdot 5\end{array}$

Chemical composition

$\begin{array}{rrr}85 \cdot 92 & 86 \cdot 77 & 86 \cdot 88 \\ 92 \cdot 51 & 92 \cdot 26 & 91 \cdot 45 \\ 11 \cdot 15 & 14 \cdot 87 & 18 \cdot 23 \\ 2 \cdot 18 & 2 \cdot 77 & 3 \cdot 20 \\ 25 \cdot 24 & 16 \cdot 22 & 8 \cdot 05 \\ 5 \cdot 06 & 3 \cdot 97 & 2 \cdot 90 \\ 7 \cdot 49 & 7 \cdot 74 & 8 \cdot 55 \\ 4 \cdot 40 & 4 \cdot 41 & 4.44\end{array}$

DM, dry matter.

* In addition, the following were added to all diets $\left(\mathrm{g} / \mathrm{r} 000 \mathrm{~kg}\right.$ ): vitamins $\mathrm{A}, \mathrm{D}_{3}$ and $\mathrm{E}$ (potencies 50000 , 10000 and $52 \cdot 5 \mathrm{i}$ i. $/ \mathrm{g}$ respectively) $200, \mathrm{CoSO}_{4} \cdot 7 \mathrm{H}_{2} \mathrm{O}$ 17, $\mathrm{FeSO}_{4} \cdot 7 \mathrm{H}_{2} \mathrm{O}_{36}, \mathrm{MnSO}_{4} \cdot 4 \mathrm{H}_{2} \mathrm{O}{ }_{1} 8$, $\mathrm{KI}(90 \%) 2$, and $\mathrm{ZnO} 20$.

+ Calculated as acid detergent fibre-lignin.

$\ddagger \mathrm{I}$ cal $=4 \cdot 184 \mathrm{~J}$.

thoroughly and subsampled by hand. One thousand individual particles were taken at random from the subsample, the length of each was measured on a linear scale and the distribution of particles over various sizes was determined; from this, the mean value 
was calculated. The composition of the concentrate was (in parts): barley 20, maize 23, wheat bran 23, decorticated groundnut meal I7, copra cake I I and palm-kernel cake 6 . The straw and concentrate were mixed in the proportions shown in Table $\mathrm{I}$, and to the final diets were added: molasses at a rate of $10 \%$; dicalcium phosphate and sodium chloride each at a rate of $\mathrm{r} \cdot 5 \%$; and vitamin and trace-element supplements. The diets were extruded through a $\mathrm{r} \cdot 6 \mathrm{~cm}$ die to give pellets approximately $5 \mathrm{~cm}$ in length. The chemical compositions of the complete diets are shown in Table $\mathrm{I}$.

\section{Determination of voluntary intake}

The total daily allowance of each diet was offered in one meal at ro.0o hours. The uneaten food was removed and weighed after $5 \mathrm{~h}$ and its dry matter determined. The amount of food offered was adjusted so that the uneaten portion was about $10 \%$ of the amount offered. Water intakes were recorded daily.

\section{Digestibility}

The total digestibility of the diets was determined by collecting the faeces with the harness and equipment described by Balch, Bartlett $\&$ Johnson (195I). The net amount of digestion occurring in the reticulo-rumen was estimated by means of the ligninratio technique (Balch, 1957; Campling, Freer \& Balch, I96r); samples of digesta were taken from a point close to the reticulo-omasal orifice, five times daily over a period of $5 \mathrm{~d}$, and were bulked for analysis.

\section{Digestion of cellulose in the rumen}

The cotton-thread technique described by Campling et al. (196I) was used to obtain an index of the rate of digestion of cellulose in the rumen.

\section{Mean time of retention of undigested food residues in the alimentary tract}

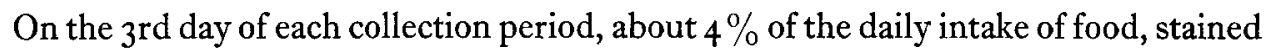
with magenta, was thoroughly mixed by hand into the rumen contents. At the same time, $50 \mathrm{~g}$ milled $(0.9 \mathrm{~mm}$ screen) food stained with Brilliant Green were suspended in warm water and introduced into the abomasum through a rubber tube inserted through the rumen fistula and the reticulo-omasal orifice. The numbers of stained particles of each colour were counted in subsequent samples of faeces (Balch, I950) and the mean times of retention of stained particles in the whole gut and in the abomasum and intestine (subsequently abbreviated to 'hind gut') were calculated by the method of Castle (1956).

\section{Amount of digesta in the gastro-intestinal tract}

The total weight of digesta and the amount of digesta dry matter in the reticulorumen were determined by manually emptying that organ and weighing, sampling and returning the contents before and after feeding on 2 consecutive days at the end of each treatment period. Total gut fill was calculated by the method of Baumgardt (1965). To find, by this method, the weight of dry matter contained in the digestive 
tract at a given time, previous intakes of food are summed after being weighted by the fraction of the undigested residue still in the tract and the fraction of the meal not digested. The numerical values of these two weighting factors are determined by the time that has elapsed between the ingestion of each meal and the time at which fill is to be calculated. To make the calculation, it is necessary that the animals are fed at equal intervals of time, and the value is made more accurate if individual daily values for food intake are used. Fill, calculated in this way, assumes instantaneous intake.

An estimate was obtained, by difference between the calculated amount of material in the whole gut and the measured amount in the reticulo-rumen, of the amount of dry matter in the omasum and hind gut.

\section{Behaviour}

The times spent eating, ruminating and resting, and the motility of the reticulum, were recorded as described by Campling \& Freer (1966), during periods of $72 \mathrm{~h}$.

\section{Chemical methods}

Dried samples of feeds, faeces and rumen digesta were bulked and analysed for ash and ether extract (Association of Official Agricultural Chemists, I965), and for lignin and acid detergent fibre by the method of Van Soest (1963). Cellulose was calculated as the difference between acid detergent fibre and lignin (Colburn \& Evans, 1965). Crude protein was determined in dried feed samples, and in faeces and rumen digesta stored under acid (Association of Official Agricultural Chemists, I965). The calorific values of dried foods and faeces were determined in an adiabatic bomb calorimeter.

\section{Statistical analyses}

Statistical analyses of the results were based on methods described by Snedecor (1956). A multiple range test (Duncan, 1955) was used to compare treatment means.

\section{Expt 2}

The influence of time of access to food on voluntary intake of complete diets was measured in a simple experiment with two of the cows previously used in Expt $\mathrm{I}$. The diets used were $\circ R$ and a mixture ( $5 \circ R$ ) of equal parts of diets $4 \circ R$ and $6 \circ R$ used in Expt $\mathrm{r}$. Voluntary intakes of each diet by each cow were determined during Io d periods with $5 \mathrm{~h}$ access, as in Expt $\mathrm{I}$, and when the cows were fed twice daily, in two equal parts at 06.00 and 18.00 hours, with $24 \mathrm{~h}$ access. When the cows had $24 \mathrm{~h}$ access, uneaten food was removed immediately before the 18.00 feed. The amount of food offered was adjusted so that the uneaten portion was about $10 \%$ of the amount given. No other measurements were made.

\section{RESULTS \\ Voluntary intake}

The mean daily intakes of water, dry matter, digestible organic matter and digestible energy by the four cows in Expt $\mathrm{I}$ are shown in Table 2. 
There were no significant differences in dry-matter intake between the three diets containing roughage. These diets were all eaten in significantly $(P<0.0 \mathrm{I})$ greater amounts than the all-concentrate diet. Digestible organic matter and digestible energy intakes were significantly $(P<0.05)$ higher for diets $20 \mathrm{R}$ and $4 \circ \mathrm{R}$ than for diets $\circ \mathrm{R}$ and $60 \mathrm{R}$. The intake of water was significantly $(P<0.05)$ less when diet $60 \mathrm{R}$ was

Table 2. Expt 1. Mean daily intakes of water, dry matter, digestible organic matter and digestible energy by four cows offered ad lib. complete diets containing different proportions of straw and concentrate

\begin{tabular}{|c|c|c|c|c|}
\hline \multirow[b]{2}{*}{$\begin{array}{c}\text { Diet } \\
\text { (see Table I) }\end{array}$} & \multicolumn{4}{|c|}{ Mean daily intake } \\
\hline & $\begin{array}{l}\text { Water } \\
(\mathrm{kg})\end{array}$ & $\begin{array}{c}\text { Dry matter } \\
(\mathrm{kg})\end{array}$ & $\begin{array}{c}\text { Digestible } \\
\text { organic matter } \\
(\mathrm{kg})\end{array}$ & $\begin{array}{c}\text { Digestible } \\
\text { energy } \\
\text { (Mcal)* }\end{array}$ \\
\hline $\begin{array}{l}6 \circ R \\
4 \circ R \\
2 \circ R \\
\circ R\end{array}$ & $\begin{array}{l}35 \cdot 9^{\mathrm{a}} \\
42 \cdot 3^{\mathrm{b}} \\
42 \cdot 5^{\mathrm{b}} \\
38 \cdot 2^{\mathrm{ab}}\end{array}$ & $\begin{array}{r}10.73^{\mathrm{A}} \\
11 \cdot 25^{\mathrm{A}} \\
10.71^{\mathrm{A}} \\
7.47^{\mathrm{B}}\end{array}$ & $\begin{array}{l}5 \cdot 5^{6^{\mathrm{a}}} \\
6 \cdot 32^{\mathrm{ab}} \\
6 \cdot 94^{\mathrm{b}} \\
5 \cdot 6 \mathrm{r}^{\mathrm{a}}\end{array}$ & $\begin{array}{l}26 \cdot 2^{\mathrm{a}} \\
29 \cdot 3^{\mathrm{ab}} \\
32 \cdot 3^{\mathrm{b}} \\
26 \cdot 2^{\mathrm{a}}\end{array}$ \\
\hline $\begin{array}{l}\text { SE of difference } \\
\text { between two } \\
\text { means }\end{array}$ & $2 \cdot 10$ & 0.63 & 0.41 & $2 \cdot 08$ \\
\hline
\end{tabular}

Means in the same column with different superscripts are significantly different: ${ }^{A},{ }^{B}, P<0.01$; a, b, $P<0.05$.

* I cal $=4 \cdot 184 \mathrm{~J}$.

Table 3. Expt 2. Mean voluntary intake of complete diets containing 50 or $0 \%$ roughage, available to two cows for 5 or $24 h$ daily

\begin{tabular}{|c|c|c|c|c|c|}
\hline \multirow[b]{2}{*}{$\begin{array}{c}\text { Diet } \\
\text { (see p. roI 7) }\end{array}$} & \multirow[b]{2}{*}{$\begin{array}{c}\text { Time of } \\
\text { access } \\
\text { (h) }\end{array}$} & \multicolumn{4}{|c|}{ Voluntary intake (kg dry matter/d) } \\
\hline & & Cow $\mathrm{G}$ & Cow $\mathrm{P}$ & Mean & $\begin{array}{c}24 \mathrm{~h} \text { value } \\
\text { as \% of } \\
5 \mathrm{~h} \text { value }\end{array}$ \\
\hline $5 \circ \mathrm{R}$ & $\begin{array}{r}5 \\
24\end{array}$ & $\begin{array}{l}13.00 \\
13.82\end{array}$ & $\begin{array}{l}\text { II } 68 \\
\text { I } 2 \cdot 07\end{array}$ & $\begin{array}{l}12 \cdot 34 \\
12.95\end{array}$ & - \\
\hline oR & $\begin{array}{r}5 \\
24\end{array}$ & $\begin{array}{l}\text { II I I I } \\
14 \cdot 04\end{array}$ & $\begin{array}{r}6 \cdot 84 \\
12 \cdot 57\end{array}$ & $\begin{array}{r}8 \cdot 98 \\
13 \cdot 31\end{array}$ & $\overline{148}$ \\
\hline
\end{tabular}

given than when the animals received either of the other diets containing roughage. There were significant $(P<0.05)$ linear relationships between water intake and the intakes of dry matter $(r=0.63)$, digestible organic matter $(r=0.66)$ and digestible energy $(r=0.63)$; the regression coefficients were $\mathrm{I} \cdot 59,3.82$ and 0.78 respectively.

When access to the complete diets was increased in the second experiment from 5 to $24 \mathrm{~h}$, the intake (Table 3 ) of diet $5 \circ \mathrm{R}$ increased to only $105 \%$ of that when the cows had $5 \mathrm{~h}$ access. However, with diet oR the mean increase was to $148 \%$, the $24 \mathrm{~h}$ intake being very similar to the $24 \mathrm{~h}$ intake of diet $5 \circ \mathrm{R}$. 


\section{Digestibility}

The digestibilities of the diets when offered ad lib. in Expt $\mathrm{I}$ are shown in Table 4. The values for digestibility in the hind gut were calculated as the differences between the digestibilities in the whole gut and in the reticulo-rumen. The differences between all diets were significant $(P<0.01)$ but the increases in digestibility with each reduction in straw content of the diet were not equal. Digestibility of the dry matter in the reticulo-rumen followed a similar pattern. On all diets, the greater part of the

Table 4. Expt 1. Mean apparent digestibilities (\%) in the whole gut, reticulo-rumen and hind gut of dry matter, organic matter, cellulose, crude protein and lignin in complete diets containing different proportions of straw and concentrate, offered ad lib. to four cows

\begin{tabular}{|c|c|c|c|c|c|}
\hline $\begin{array}{c}\text { Diet } \\
\text { (see Table } \mathrm{r})\end{array}$ & $\begin{array}{c}\text { Dry } \\
\text { matter }\end{array}$ & $\begin{array}{l}\text { Organic } \\
\text { matter }\end{array}$ & Cellulose & $\begin{array}{c}\text { Crude } \\
\text { protein }\end{array}$ & Lignin \\
\hline \multicolumn{6}{|c|}{ Digestibility in whole gut } \\
\hline $\begin{array}{l}6 \circ R \\
4 \circ R \\
20 R \\
\circ R\end{array}$ & $\begin{array}{l}55^{\cdot} \cdot 1^{\mathrm{A}} \\
59^{\cdot} \mathrm{I}^{\mathrm{B}} \\
69^{\cdot} \cdot \mathrm{I}^{\mathrm{C}} \\
80 \cdot 6^{\mathrm{D}}\end{array}$ & $\begin{array}{l}56 \cdot 4^{A} \\
60 \cdot 8^{B} \\
70 \cdot 6^{\mathrm{C}} \\
82 \cdot 6^{D}\end{array}$ & $\begin{array}{l}49^{\cdot} 9^{\mathrm{b}} \\
47 \cdot 1^{\mathrm{ab}} \\
42 \cdot 9^{\mathrm{a}} \\
58 \cdot 5^{\mathrm{c}}\end{array}$ & $\begin{array}{l}51 \cdot 6^{\mathrm{A}} \\
56 \cdot 9^{\mathrm{A}} \\
72 \cdot 6^{\mathrm{B}} \\
78 \cdot 3^{\mathrm{B}}\end{array}$ & $\begin{array}{r}-4.4 \\
0.7 \\
7 \cdot 2 \\
10.5\end{array}$ \\
\hline $\begin{array}{l}\text { SE of difference } \\
\text { between } \\
\text { two means }\end{array}$ & 0.34 & 0.83 & $2 \cdot 27$ & $2 \cdot 14$ & - \\
\hline \multicolumn{6}{|c|}{ Digestibility in reticulo-rumen } \\
\hline $\begin{array}{l}6 \circ R \\
4 \circ R \\
20 R \\
\circ R\end{array}$ & $\begin{array}{l}33 \cdot 3^{\mathrm{A}} \\
40 \cdot 8^{\mathrm{B}} \\
5 \mathrm{I} \cdot 4^{\mathrm{C}} \\
65 \cdot 0^{\mathrm{D}}\end{array}$ & $\begin{array}{l}35 \cdot 6^{\mathrm{A}} \\
42 \cdot 6^{\mathrm{B}} \\
52 \cdot 5^{\mathrm{C}} \\
67 \cdot 8^{\mathrm{D}}\end{array}$ & $\begin{array}{l}28 \cdot 6^{B} \\
26 \cdot 8^{B} \\
12 \cdot 2^{A} \\
50 \cdot 4^{O}\end{array}$ & $\begin{array}{l}20 \cdot 1^{\mathrm{a}} \\
30 \cdot 6^{\mathrm{b}} \\
42 \cdot 5^{\mathrm{c}} \\
4 I \cdot 2^{\mathrm{c}}\end{array}$ & - \\
\hline $\begin{array}{l}\text { SE of difference } \\
\text { between } \\
\text { two means }\end{array}$ & $\mathbf{I} \cdot 39$ & $I \cdot 42$ & $3 \cdot 03$ & $3 \cdot 56$ & - \\
\hline \multicolumn{6}{|c|}{ Digestibility in hind gut (by difference) } \\
\hline $\begin{array}{l}6 \circ R \\
4 \circ R \\
20 R \\
\circ R\end{array}$ & $\begin{array}{l}21 \cdot 8^{a} \\
18 \cdot 3^{a b} \\
17 \cdot 7^{b} \\
15 \cdot 6^{b}\end{array}$ & $\begin{array}{l}20 \cdot 8^{\mathrm{a}} \\
18 \cdot 2^{\mathrm{ab}} \\
18 \cdot \mathrm{I}^{\mathrm{ab}} \\
14 \cdot 8^{\mathrm{b}}\end{array}$ & $\begin{array}{l}21 \cdot 3^{B} \\
20 \cdot 3^{B} \\
30 \cdot 7^{A} \\
8 \cdot 1^{C}\end{array}$ & $\begin{array}{l}3 I \cdot 5^{a b} \\
26 \cdot 3^{a} \\
30 \cdot I^{a b} \\
37 \cdot I^{b}\end{array}$ & - \\
\hline $\begin{array}{l}\text { SE of difference } \\
\text { between } \\
\text { two means }\end{array}$ & $1 \cdot 58$ & $1 \cdot 53$ & $x \cdot 76$ & $2 \cdot 90$ & - \\
\hline
\end{tabular}

Means in the same column with different superscripts are significantly different: ${ }^{\mathrm{A}},{ }^{\mathrm{B}},{ }^{\mathrm{C}},{ }^{\mathrm{D}}, P<0.0 \mathrm{I}$; a, b, c, d, $P<0.05$.

digestible dry matter disappeared in the reticulo-rumen, the proportion increasing with decreasing straw content of the diet from $60 \%$ on diet $60 \mathrm{R}$ to $80 \%$ on diet $\circ \mathrm{R}$. In the hind gut there was a decline in the amount of the total dry matter digested as the proportion of straw in the diet declined, but the variation between diets was much less than in the reticulo-rumen. Significantly $(P<0.05)$ more of the dry matter of diet $60 \mathrm{R}$ than of $20 \mathrm{R}$ or $\circ \mathrm{R}$ was digested in the hind gut; no other differences between diets were significant. The digestibility of the organic matter of the four diets closely paralleled that of the dry matter in all parts of the alimentary tract.

With diets $4 \circ \mathrm{R}$ and $60 \mathrm{R}$, about half the cellulose consumed was digested, slightly more disappearing in the reticulo-rumen than in the hind gut. The total digestibility 
of the cellulose of diet $20 \mathrm{R}$ was only a little less than that of the two high-roughage diets. However, the digestion of cellulose in the reticulo-rumen was severely depressed in comparison with that in the two high-roughage diets, and this difference was significant $(P<0.01)$. In contrast, the disappearance of digestible cellulose in the hind gut was significantly $(P<0.01)$ greater than when diet $60 \mathrm{R}$ or $40 \mathrm{R}$ was given. Nearly $60 \%$ of the cellulose of the all-concentrate diet was digested; this was signifcantly $(P<0.01)$ more than with any of the diets containing straw. Most of this digestion took place in the reticulo-rumen, where the cellulose digestibility was significantly $(P<0.01)$ higher than with any of the roughage diets.

Significantly $(P<0.05)$ more nitrogen of diet $40 \mathrm{R}$ than of diet $60 \mathrm{R}$ disappeared from the reticulo-rumen. The total digestibility of the crude protein of diets $\circ R$ and $20 \mathrm{R}$ was significantly $(P<0.0 \mathrm{r})$ greater than that of the two high-roughage diets, owing mainly to a significantly $(P<0.05)$ greater digestibility in the reticulo-rumen. When diet $\mathrm{O}$ was given, the digestibility of crude protein in the hind gut was also significantly $(P<0.05)$ greater than that of diet $40 \mathrm{R}$.

The digestibility of lignin ranged from $-4 \%$ to $+\mathrm{II} \%$; thus faecal recoveries of lignin were very close to the range $90-110 \%$ considered necessary for accurate application of the lignin-ratio technique (Balch, 1957).

\section{Amounts of digesta in the reticulo-rumen and hind gut}

Before a meal, the amounts of wet digesta and digesta dry matter present in the reticulo-rumen were smallest in cows receiving diet $\mathrm{OR}$ and $20 \mathrm{R}$ ('Table 5). The greatest amounts were present when diet $60 \mathrm{R}$ was given, these being significantly

Table 5. Expt I. Mean amounts (kg) of digesta and digesta dry matter in the reticulorumen of four cows before and after feeding ad lib. on complete diets containing different proportions of straw and concentrate

\begin{tabular}{|c|c|c|c|c|}
\hline \multirow[b]{2}{*}{$\begin{array}{c}\text { Diet } \\
\text { (see Table I) }\end{array}$} & \multicolumn{2}{|c|}{ Before feeding } & \multicolumn{2}{|c|}{ After feeding } \\
\hline & Total digesta & $\begin{array}{l}\text { Digesta dry } \\
\text { matter }\end{array}$ & Total digesta & $\begin{array}{c}\text { Digesta dry } \\
\text { matter }\end{array}$ \\
\hline $\begin{array}{r}6 \circ R \\
4 \circ R \\
2 \circ R \\
\circ R\end{array}$ & $\begin{array}{l}64 \cdot 0^{\mathrm{C}} \\
54^{\cdot} \cdot 9^{\mathrm{BC}} \\
43^{\cdot} \cdot \mathrm{I}^{\mathrm{A}} \\
45^{\circ} \cdot 9^{\mathrm{AB}}\end{array}$ & $\begin{array}{l}6 \cdot 78^{\mathrm{A}} \\
5 \cdot 64^{\mathrm{A}} \\
3 \cdot 95^{\mathrm{B}} \\
3 \cdot 63^{\mathrm{B}}\end{array}$ & $\begin{array}{l}92 \cdot 9^{\mathbf{A}} \\
86 \cdot 3^{A} \\
71 \cdot 9^{B} \\
59 \cdot 8^{\mathrm{C}}\end{array}$ & $\begin{array}{r}13.95^{\mathrm{A}} \\
12.82^{\mathrm{A}} \\
9.52^{\mathrm{B}} \\
6.67^{\mathrm{C}}\end{array}$ \\
\hline $\begin{array}{l}\text { SE of difference } \\
\text { between two } \\
\text { means }\end{array}$ & $2 \cdot 84$ & 0.42 & 3.09 & 0.66 \\
\hline
\end{tabular}

Means in the same column with different superscripts are significantly different $(P<0.01)$.

$(P<0.01)$ more than when $\circ \mathrm{R}$ and $20 \mathrm{R}$ were given. In cows receiving diet $4 \circ \mathrm{R}$, there were significantly $(P<0.01)$ more digesta in the rumen than in cows receiving $20 \mathrm{R}$ and the amount of digesta dry matter was significantly $(P<0.01)$ greater than in cows receiving either of the low-roughage diets.

After a meal, there was a highly significant $(P<0.001)$ linear relationship $(r=-0.92)$ between the total amount of digesta in the reticulo-rumen and the digestibility of the 
diet (Fig. I). There were significant $(P<0.0 \mathrm{I})$ differences between $4 \circ \mathrm{R}$ and $20 \mathrm{R}$, and between $20 \mathrm{R}$ and $\circ \mathrm{R}$, in the amounts of digesta and digesta dry matter in the reticulo-rumen.

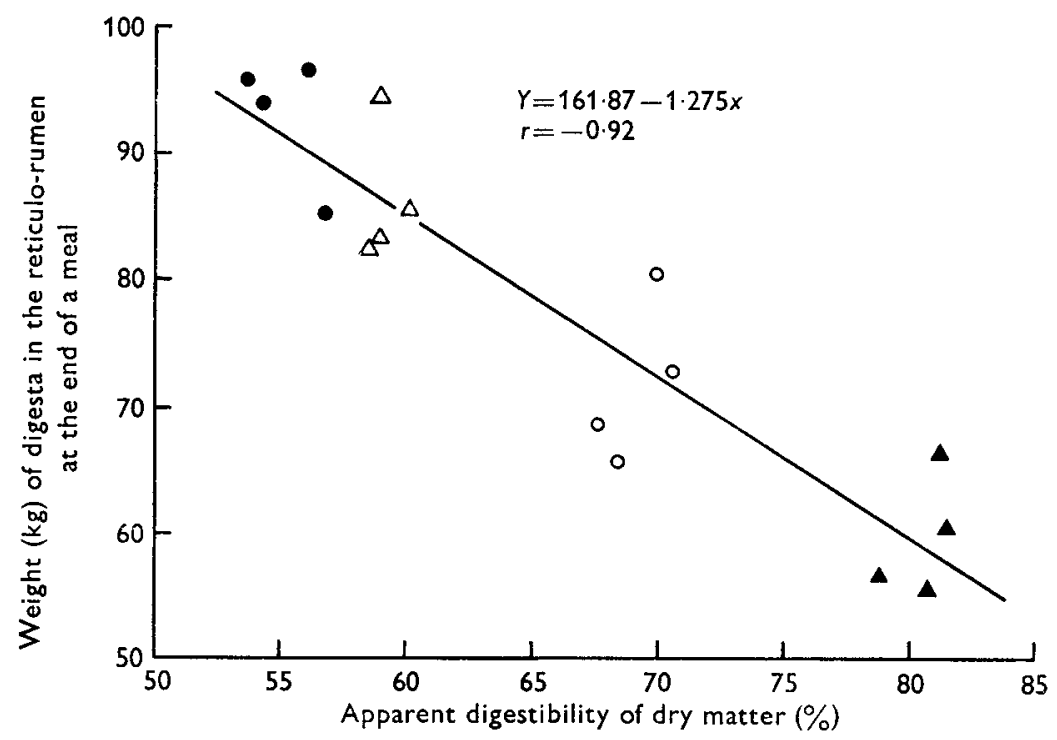

Fig. I. The relationship between the weight of digesta in the reticulo-rumen at the end of a meal and the apparent digestibility of the dry matter of the diet when complete diets containing concentrates and $60 \%(\bullet), 40 \%(\triangle), 20 \%(O)$ or $\circ \%(\Delta)$ barley straw were offered ad lib. to four cows.

Table 6. Expt I. Amount of dry matter ( $\mathrm{kg}$ ) in the reticulo-rumen of cows on the Ist day of rumen emptying together with the total amount of dry matter ( $\mathrm{kg})$ in the whole gut (calculated according to Baumgardt, 1965) and, by difference, the amount of dry matter $(\mathrm{kg})$ in the gut distal to the reticulo-rumen

\begin{tabular}{|c|c|c|c|}
\hline \multirow{2}{*}{$\begin{array}{c}\text { Diet } \\
\text { (see Table I) }\end{array}$} & \multicolumn{3}{|c|}{ Dry matter in different parts of the alimentary cana } \\
\hline & Total & Reticulo-rumen & Hind gut \\
\hline $\begin{array}{l}60 R \\
40 R\end{array}$ & $\begin{array}{l}19.74^{\mathrm{bc}} \\
2 \times .02^{\mathrm{c}}\end{array}$ & $\begin{array}{l}13.84 \\
12.56\end{array}$ & $\begin{array}{l}5 \cdot 90^{\mathrm{a}} \\
8 \cdot 46^{\mathrm{b}}\end{array}$ \\
\hline $20 \mathrm{R}$ & $18 \cdot 98^{b}$ & $9 \cdot 59$ & $9 \cdot 39^{\mathrm{b}}$ \\
\hline oR & $10.53^{a}$ & 6.59 & $3.94^{\mathrm{a}}$ \\
\hline
\end{tabular}

Means in the same column with different superscripts are significantly different $(P<0.05)$.

The calculated amounts of dry matter in the whole alimentary canal on the ist day of rumen emptying are given in Table 6 . The measured amounts of dry matter in the reticulo-rumen at the end of feeding are also given, together with the amount of dry matter in the omasum, abomasum and intestines, calculated as the difference between the above amounts. The contents of the whole gut were greatest when diet $4 \circ \mathrm{R}$ was given, being significantly $(P<0.05)$ greater than when $\circ \mathrm{R}$ or $20 \mathrm{R}$ was given. When 
diet $\circ \mathrm{R}$ was given, the contents of the whole gut were significantly $(P<0.05)$ less than when any of the other diets was given. In the gut distal to the reticulo-rumen, the greatest amount of material was found in cows receiving diet $20 \mathrm{R}$. Cows receiving diet $\circ \mathrm{R}$ or $6 \circ \mathrm{R}$ had significantly $(P<0.05)$ less digesta in the hind gut than those receiving $20 \mathrm{R}$ or $40 \mathrm{R}$.

\section{Digestion of cellulose in the rumen}

The times taken for cotton threads placed in the ventral sac of the rumen to lose $25 \%$ of their weight were least in cows receiving diet $4 \circ \mathrm{R}$ and $60 \mathrm{R}$, there being no difference between the values with these diets (Table 7 ). On diet $20 \mathrm{R}$, the time taken

Table 7. Expt 1. Time for $25 \%$ loss of weight of cotton threads placed in the ventral sac of the rumen of four cows offered ad lib. complete diets containing different proportions of straw and concentrate

$\begin{array}{cc}\begin{array}{c}\text { Diet } \\ \text { (see Table I) }\end{array} & \begin{array}{c}\text { Time (h) for } 25 \% \\ \text { loss of weight }\end{array} \\ 6 \circ \mathrm{R} & 29 \cdot 6 \\ \text { 4०R } & 28.5 \\ 20 \mathrm{R} & >60 \\ \text { OR } & >120\end{array}$

Table 8. Expt I. Mean retention time in the whole gut, hind gut and reticulo-rumen of undigested residues of complete diets, containing different proportions of straw and concentrate, offered ad lib. to four cows

$\begin{array}{lccc}\begin{array}{c}\text { Diet } \\ \text { (see Table I) }\end{array} & \text { Whole gut } & \text { Hind gut } & \begin{array}{c}\text { Reticulo-rumen } \\ \text { (by difference) }\end{array} \\ 60 \mathrm{R} & 61 \cdot 2^{\mathrm{a}} & 16 \cdot 7^{\mathrm{ab}} & 44 \cdot 5^{\mathrm{a}} \\ 40 \mathrm{R} & 59 \cdot 0^{\mathrm{a}} & 12 \cdot 2^{\mathrm{a}} & 46 \cdot 8^{\mathrm{ab}} \\ 20 \mathrm{R} & 69 \cdot 7^{\mathrm{a}} & 13 \cdot 3^{\mathrm{a}} & 56 \cdot 4^{\mathrm{b}} \\ \text { OR } & 62 \cdot 5^{\mathrm{a}} & 19 \cdot 5^{\mathrm{b}} & 43^{\circ} \\ \text { SE of difference } & 4 \cdot 86 & 2 \cdot 24 & 4 \cdot 09 \\ \text { between } & & & \end{array}$

Means in the same column with different superscripts are significantly different $(P<0.05)$.

was in excess of $60 \mathrm{~h}$, more than twice that taken on the two high-roughage diets. When the all-concentrate diet was given, there was no loss of weight of cotton threads after $5 \mathrm{~d}$ in three of the cows. In the fourth cow, cotton threads lost $25 \%$ of their weight after $47 \mathrm{~h}$; during the experiment, this animal had received the diets in the order $6 \circ \mathrm{R}, t_{\mathrm{r}} \circ \mathrm{R}, 20 \mathrm{R}$ and $\circ \mathrm{R}$.

\section{Mean time of retention of undigested food residues in the alimentary tract}

The mean time of retention in the gut of undigested residues of the four diets varied greatly between cows, so few of the observed differences were significant.

In the hind gut, residues of diet $\circ \mathrm{R}$ were retained for a significantly $(P<0.05)$ 
longer time than residues of diet $20 \mathrm{R}$ and $4 \circ \mathrm{R}$. In the reticulo-rumen, the longest retention time was for residues of diet $20 \mathrm{R}$, being significantly $(P<0.05)$ greater than for those of diet $\circ \mathrm{R}$ or $60 \mathrm{R}$.

\section{Behaviour}

The behaviour of the cows in Expt $\mathrm{I}$ is shown in Table 9. In this table 'resting' refers to all activity other than eating or ruminating. The mean time spent daily eating the four diets declined as the percentage of roughage in the diet was reduced. In relation to the amount of dry matter consumed, cows receiving $\circ R$ spent the greatest amount of time eating, the time being significantly $(P<0.05)$ greater than in cows

Table 9. Expt 1. Mean daily time spent eating, ruminating and resting, and the frequency of reticular contractions during each activity when complete diets, containing different proportions of straw and concentrate, were offered to four cows

\begin{tabular}{|c|c|c|c|c|c|c|c|c|c|}
\hline \multirow{2}{*}{$\begin{array}{c}\text { Diet } \\
\text { (see } \\
\text { Table I) }\end{array}$} & \multicolumn{3}{|c|}{ Time (min) } & \multicolumn{3}{|c|}{ Contractions/100 min } & \multirow{2}{*}{$\begin{array}{c}\text { Time } \\
\text { spent } \\
\text { ruminating/ } \\
\text { kg straw } \\
\text { DM eaten } \\
\text { (min) }\end{array}$} & \multirow{2}{*}{$\begin{array}{l}\text { Time } \\
\text { spent } \\
\text { eating } / \mathrm{kg} \\
\text { total } \\
\text { DM eaten } \\
\text { (min) }\end{array}$} & \multirow{2}{*}{$\begin{array}{c}\text { Time } \\
\text { between } \\
\text { start of } \\
\text { feeding } \\
\text { and first } \\
\text { rumination } \\
\text { (min) }\end{array}$} \\
\hline & Eating & $\begin{array}{l}\text { Rumi- } \\
\text { nating }\end{array}$ & Resting & Eating & $\begin{array}{l}\text { Rumi- } \\
\text { nating }\end{array}$ & Resting & & & \\
\hline $\begin{array}{r}60 R \\
4 \circ R \\
20 R \\
\circ R\end{array}$ & $\begin{array}{l}198^{c} \\
190^{b c} \\
168^{a b} \\
154^{a}\end{array}$ & $\begin{array}{r}468^{\mathrm{C}} \\
409^{\mathrm{O}} \\
218^{\mathrm{B}} \\
0^{\mathrm{A}}\end{array}$ & $\begin{array}{r}774^{\mathrm{O}} \\
84 \mathrm{I}^{\mathrm{O}} \\
1054^{\mathrm{B}} \\
1286^{\mathrm{A}}\end{array}$ & $\begin{array}{l}177^{b} \\
184^{c} \\
180^{b c} \\
168^{a}\end{array}$ & $\begin{array}{c}103^{\mathrm{a}} \\
102^{\mathrm{a}} \\
107^{\mathrm{a}} \\
-\end{array}$ & $\begin{array}{l}122^{c} \\
118^{b c} \\
105^{a b} \\
102^{a}\end{array}$ & $\begin{array}{r}72 \cdot 6 \\
91 \cdot 2 \\
102 \cdot 5 \\
-\end{array}$ & $\begin{array}{l}18 \cdot 4^{a b} \\
17 \cdot 0^{a} \\
15 \cdot 7^{a} \\
20 \cdot 8^{b}\end{array}$ & $\begin{array}{l}163^{\mathrm{A}} \\
\mathrm{I} 84^{\mathrm{A}} \\
54 \mathrm{I}^{\mathrm{B}} \\
705^{* \mathrm{C}}\end{array}$ \\
\hline $\begin{array}{l}\mathrm{SE} \text { of } \\
\text { difference } \\
\text { between } \\
\text { two means }\end{array}$ & $9 \cdot 4$ & $24 \% 4$ & $24 \cdot 7$ & $2 \cdot 6$ & $5 \cdot 5$ & $5 \cdot 9$ & - & $1 \cdot 27$ & $40 \cdot \mathrm{I}$ \\
\hline
\end{tabular}

DM, dry matter.

Means in the same column with different superscripts are significantly different: ${ }^{A},{ }^{\mathrm{B}},{ }^{\mathrm{C}}, P<0.0 \mathrm{I}$; a, b, c, $P<0.05$.

* First triple contractions of reticulo-rumen.

given $2 \circ \mathrm{R}$ or $4 \circ \mathrm{R}$, but not significantly greater than $6 \circ \mathrm{R}$. The rate of reticular contractions during eating was greatest on $4 \circ \mathrm{R}$, the rate being significantly $(P<0.05)$ faster than on $\circ \mathrm{R}$ or $6 \circ \mathrm{R}$. The rate recorded with $\circ \mathrm{R}$ was significantly $(P<0.05)$ lower than with any of the other diets.

Similarly, the mean daily time spent ruminating decreased as the proportion of straw in the diet decreased. On $20 \mathrm{R}$ the time spent ruminating was significantly $(P<0.01)$ less than on $6 \circ \mathrm{R}$ and $4 \circ \mathrm{R}$, and more than on $\circ \mathrm{R}$, when there was no true rumination at all. When diet $\mathrm{R}$ was given, periods of triple reticular contractions, without the corresponding jaw movements, were noted in all cows; they were similar to those observed by Freer \& Campling ( 1965$)$ in cows fed an all-concentrate diet. In relation to the amount of straw dry matter eaten, there was an increase in the daily time spent ruminating as the proportion of straw in the diet decreased. There were no differences between treatments in the rate of reticular contractions during rumination.

The time between the start of eating and the first subsequent period of rumination increased as the proportion of straw in the diet decreased. On both diets $6 \circ \mathrm{R}$ and $4 \circ \mathrm{R}$ there were up to three periods of rumination while the cows still had access to food. 
When diet $20 \mathrm{R}$ was given, the first period of rumination did not start until $9 \mathrm{~h}$ after food was offered; this was significantly $(P<0 \circ 0 \mathrm{r})$ later than when $60 \mathrm{R}$ or $40 \mathrm{R}$ was given. In no instance did cows given diet $20 \mathrm{R}$ ruminate while they still had access to food. In cows given diet $\circ \mathrm{R}$, triple contractions of the reticulum were not seen until nearly $12 \mathrm{~h}$ after the food was first offered.

As the proportion of roughage in the diet decreased, the time spent daily in resting increased, being significantly $(P<0 \circ \circ)$ less on $6 \circ \mathrm{R}$ and $4 \circ \mathrm{R}$ than on $2 \circ \mathrm{R}$, and less on $2 \circ \mathrm{R}$ than on $\circ \mathrm{R}$, and the rate of reticular contraction during resting decreased.

\section{DISCUSSION}

In Expt I, cows were given ad lib. access to food for $5 \mathrm{~h}$ daily; under this regimen, dry-matter intakes did not increase with increasing digestibility of the diets containing roughage. Intakes of digestible energy were greatest when diet $20 \mathrm{R}$ was given; there was a large fall in intake of both dry matter and digestible energy with the change from $20 \mathrm{R}$ to $\circ \mathrm{R}$. Thus, there was no evidence of an increase in dry-matter intake with increasing digestibility of the diets containing roughage, as has been observed by many workers, including Blaxter et al. (1961) and Ulyatt et al. (x967). Owing to the low intake of diet $\mathrm{oR}$, there was also no evidence of a constant maximum level of energy intake being achieved as the proportion of roughage in the ration decreased, as was noted by Montgomery \& Baumgardt (1965). However, Baumgardt (1970) has pointed out that energy intake is often less on diets of very high energy content than on diets that are moderately high in energy. Also, had the animals had access to food for $24 \mathrm{~h}$ daily, energy intake might have become more constant among diets as the intake in Expt 2 of diet $\circ \mathrm{R}$ increased by a much greater margin relative to the $5 \mathrm{~h}$ intake than did that of the diet of lower digestibility and higher roughage content (see Table 3 ). Freer \& Campling (1963) have also observed this relative change in intakes of concentrates and roughages as the time of access is increased.

Consideration must be given to the extent to which intake may have been influenced by the decrease in crude-protein content of the rations as the proportion of roughage in the diet increased (Table I). Elliott $(1967 a)$ pointed out that level of protein in the diet, below approximately $10 \%$ crude protein, affects voluntary intake by ruminants. He found that the concept of a positive correlation between intake and digestibility of a food was valid only when protein intake was at least $4 \mathrm{~g}$ digestible crude protein $/ \mathrm{kg}$ $W^{0.73}$ per d. In the present work, diet $60 \mathrm{R}$ contained $9 \cdot 15 \%$ crude protein and supplied $5.2 \mathrm{~g}$ digestible crude protein $/ \mathrm{kg} W^{70.73}$ per d when eaten $a d l i b$. Kay, Bowers $\&$ McKiddie (1968) in experiments with young, rapidly growing steers observed lowered intake and digestibility of a concentrate diet containing I $\%$ crude protein when compared with diets containing $\mathrm{x}_{4}$ or $\mathrm{I} 7 \%$ crude protein. However, it seems likely that the critical protein level would be lower in mature animals with a lower protein requirement. With sheep, crude protein contents near $8 \%$ have been found adequate to maximize intake (Elliott \& Topps, 1963 ; Blaxter \& Wilson, 1963 ), although Elliott ( $1967 b$ ) has suggested that cattle have higher protein requirements than sheep. It is thus possible that the intake of diet $6 \circ \mathrm{R}$ may have been marginally reduced owing to its low protein content, 
but it seems unlikely that intakes of the other diets would have been influenced in this way. A decline in the intake of mixed diets of high roughage content was also observed by Swan \& Lamming ( 1967 ) in an experiment in which the crude-protein content of all diets was standardized at $12 \%$.

The differences in intake observed in the present study are, in effect, differences in intake at individual meals and reflect differences in the mechanism of regulation of intake of the different diets used. The cows did not eat to a constant fill of their rumen, as has been observed in sheep consuming roughages of different quality (Blaxter et al. 196I; Ulyatt et al. 1967). The high negative correlation between the amount of material in the reticulo-rumen at the end of a meal and the digestibility of the dry matter consumed in that meal (Fig. I) indicates a steady decline in the importance of distension of the rumen in controlling intake, as digestibility increases. The total amounts of digesta in the reticulo-rumen at the end of the feeding period were of the same order for diets $4 \circ \mathrm{R}$ and $60 \mathrm{R}$, suggesting that the maximum fill of this organ was closely approached when these higher-roughage diets were given. However, the relatively high rates of passage and rapid rates of cellulose breakdown when these diets were given reduced the margins between these diets and diets $20 \mathrm{R}$ and $\circ \mathrm{R}$ in the amount of material in the rumen before feeding; nevertheless, this margin was still significant, there being no tendency towards equality of rumen fill before feeding, as was observed by Campling, Freer \& Balch (I962) when various roughages were given. This agrees with the finding of Freer \& Campling ( 1963$)$ that the amount of material in the rumen was less before a meal of concentrates than before a meal of roughage.

There was no evidence that distension of the hind gut limited intake of diet $\circ \mathrm{R}$ because the calculated value for fill in the hind gut (Table 6) was lower for this diet than for any of the diets containing straw. Furthermore, it seems unlikely that the energy intake, when this diet was given, was limited by the energy requirements of the cows receiving the diet, since more energy was consumed with $20 \mathrm{R}$ or $4 \circ \mathrm{R}$ than with $\circ \mathrm{R}$. Thus, it must be concluded that some product or products of digestion in some way limited the intake of the all-concentrate diet to a much greater extent than it limited the intake of the other diets. The nature of these products will be discussed in a later paper. Unlike the work of Freer \& Campling (1963), only small differences between cows in the main site of digestion of the all-concentrate ration were observed. The amount of the total digestible organic matter disappearing in the rumen ranged only from $8 \mathrm{r} \cdot 3$ to $84 \cdot 4 \%$ for the four cows given diet o R; it is unlikely, therefore, that there were large differences in the proportions of food digested to volatile fatty acids and to monosaccharides.

It is more difficult to determine the nature of the signal causing the cows to stop eating diet $20 \mathrm{R}$. Distension of the reticulo-rumen is not likely to have exerted a major influence, the amount of digesta in this organ after a meal being substantially lower than when diet $4 \circ \mathrm{R}$ or $60 \mathrm{R}$ was given. The amount of dry matter in the hind gut was greatest when $20 \mathrm{R}$ was given and may have exerted a physical effect restricting further intake. Intake of $20 \mathrm{R}$ may have been adequate to meet the energy requirements of the cows, in which event an accumulation of energy-yielding metabolites in the blood may have caused the cessation of eating. 
The total digestibility of the cellulose of the three diets containing roughage declined as the proportion of concentrate in the diet increased. There was a parallel decline in the digestibility of cellulose in the reticulo-rumen and this corresponded to a decline in the rate of loss of weight of cotton threads. However, the cellulose of the all-concentrate diet was digested to a greater extent than that of any of the diets containing roughage. This high coefficient of digestion was almost entirely due to digestion of cellulose in the reticulo-rumen, yet in only one cow on this diet was there any measurable loss of weight of cotton threads in the rumen. The lower recovery of lignin from the faeces of cows given this diet (see Table 4) was not sufficient to account for a difference of this size. Nelson, Ellzey, Morgan \& Allen (1968) have observed a similar elevated digestion of the cellulose of a mixed all-concentrate diet but have not partitioned this digestion between the rumen and the hind gut. No explanation is offered for this observation.

The total digestibility of dry matter (and of organic matter, which follows a similar pattern) of all four diets increased as the proportion of concentrates in the diet increased. The reticulo-rumen played an increasingly important part in the digestion of the dry matter as the proportion of concentrates in the diet increased, presumably owing to the increase in the proportion of readily fermentable constituents, and the net measurements available provided no evidence of any tendency for the more concentrated diets to escape rumen fermentation and to be digested extensively in the hind gut. The increasing digestibility of dry matter in the rumen with increasing proportion of concentrates in the diet was related to an increased retention time in the rumen for the diets containing roughage, but for diet $\mathrm{R}$ the highest digestibility in the reticulo-rumen occurred in conjunction with the lowest retention time. The absence of straw particles requiring physical diminution before passage through the reticulo-omasal orifice had apparently permitted a much reduced mean retention time in the rumen of undigested residues of this diet, the components of the concentrate mixture being digested to a much greater extent during their time in the rumen than were the constituents of the dry matter of the straw in the mixed diets. The increased digestibility in the rumen of the dry matter of diet $20 \mathrm{R}$, relative to that of $4 \circ \mathrm{R}$ and $60 \mathrm{R}$, offers an explanation for the lower amount of dry matter in the rumen at the end of a meal of this diet, even though the intake was similar to that of diet $4 \circ \mathrm{R}$ and $60 \mathrm{R}$, and the mean retention time was longer.

Although, on all diets, substantially more of the total dry matter digested disappeared in the rumen than in the hind gut, on a net basis, the hind gut played a much greater part in the total apparent digestion of crude protein on all diets; with diet $60 \mathrm{R}$ it accounted for over $50 \%$ of the total protein digested. It is interesting to speculate on the extent to which this was due to an influx of endogenous nitrogen into the rumen, especially when the cows were receiving the diets of higher roughage content.

The straw used in the diets in the present experiment was chopped rather than ground in an attempt to avoid the various complications associated with the use of ground roughages; these complications include increased intake and rate of passage, decreased digestibility, absence of true rumination and a possible limiting effect of hind gut capacity on intake (Campling \& Freer, I966). It is difficult to estimate the 
extent to which this attempt was successful in an experiment in which the straw was not given alone in any treatment. However, the information on behaviour (Table 9) provides good evidence that the chopped straw was as effective as long roughage in stimulating rumination in those animals that received it. On the highest roughage diet, the total time spent ruminating approached $8 \mathrm{~h}$ daily, or 72 min per $\mathrm{kg}$ straw dry matter consumed, which agrees well with the findings of Freer, Campling $\&$ Balch (1962) in cows fed on long oat straw with or without urea.

The reduced frequency of reticular contractions, together with the long period of time elapsing between the start of feeding and the onset of triple reticular contractions in cows receiving diet $o \mathrm{R}$, suggest that the absence of roughage or low rumen $\mathrm{pH}$ may have partly inhibited the motility of the reticulo-rumen. However, the relatively small difference in these two measurements between diets $\circ \mathrm{R}$ and $20 \mathrm{R}$ seems unlikely to have been a major contributory factor to the large difference in intake between these diets.

In conclusion, it can be stated that, as the proportion of roughage in the cow's diet is reduced, there is an obvious decline in the importance of distension of the reticulorumen in the regulation of food intake. On diets of lower roughage content, distension of the hind gut may assume some importance, but when roughage is excluded completely distension of neither the reticulo-rumen nor the hind gut appears to be of any significance in food intake regulation. When an all-concentrate diet is given, and possibly also with diets containing low proportions of roughage, it is necessary to seek other control mechanisms probably dependent upon concentrations of chemical substances within the gut or after absorption therefrom; this will be the subject of a subsequent paper.

We thank Dr C. C. Balch for much helpful advice during the designing and running of this experiment and in the preparation of this paper. Sincere thanks are due to $\mathrm{Mr}$ V.W. Johnson and his colleagues for skilled care of the experimental animals and for assistance with rumen emptyings. We thank also members of the Chemistry Department for the analyses of foods and faeces. The experimental diets were supplied by U.K. Compound Feeds Ltd, Bromborough, Cheshire, to whom sincere thanks are due.

\section{REFERENCES}

Association of Official Agricultural Chemists (1965). Official Methods of Analysis roth ed. Washington, D.C. : Association of Official Agricultural Chemists.

Balch, C. C. (1950). Br. F. Nutr. 4, 36r.

Balch, C. C. (1957). Br. F. Nutr. Ir, 2 I3.

Balch, C. C., Bartlett, S. \& Johnson, V. W. (r95r). F. agric. Sci., Camb. 4r, 98.

Balch, C. C. \& Campling, R. C. (1962). Nutr. Abstr. Rev. 32, 669.

Baumgardt, B. R. (1965). F. Dairy Sci. 48, 619.

Baumgardt, B. R. (1970). In Physiology of Digestion and Metabolism in the Ruminant p. 235

[A. T. Phillipson, editor]. Newcastle upon Tyne: Oriel Press.

Blaxter, K. L. (1950-I). Nutr. Abstr. Rev. 20, I.

Blaxter, K. L. \& Wilson, R. S. (1963). Anim. Prod. 5, 27.

Blaxter, K. L., Wainman, F. W. \& Wilson, R. S. (196r). Anim. Prod. 3, 5 I.

Campling, R. C. \& Freer, M. (1966). Br. F. Nutr. 20, 229.

Campling, R. C., Freer, M. \& Balch, C. C. (196r). Br. F. Nutr. r5, 53 r. 
Campling, R. C., Freer, M. \& Balch, C. C. (1962). Br. F. Nutr. 16, I 5.

Castle, E. J. (1956). Br. F. Nutr. 10, I5.

Colburn, M. W. \& Evans, J. L. (1965). J. Dairy Sci. 48, I 557.

Duncan, D. B. (I955). Biometrics II, I.

Elliott, R. C. (1967a). F. agric. Sci., Camb. 69, 375.

Elliott, R. C. (1967b). F. agric. Sci., Camb. 69, 383 .

Elliott, R. C. \& Topps, J. H. (1963). Anim. Prod. 5, 269.

Freer, M. \& Campling, R. C. (1963). Br. . Nutr. 17, 79.

Freer, M. \& Campling, R. C. (1965). Br. Y. Nutr. r9, 195.

Freer, M., Campling, R. C. \& Balch, C. C. (1962). Br. $\mathscr{J}$. Nutr. I6, 279.

Kay, M., Bowers, H. B. \& McKiddie, G. (1968). Anim. Prod. ıo, 37.

Montgomery, M. J. \& Baumgardt, B. R. (1965). F. Dairy Sci. 48, 569.

Nelson, B. D., Ellzey, H. D., Morgan, E. B. \& Allen, M. (1968). F. Dairy Sci. 5I, 1796.

Snedecor, G. W. ( 1956). Statistical Methods 5 th ed. Ames, Iowa: Iowa State University Press.

Swan, H. \& Lamming, G. E. (1967). Anim. Prod. 9, 203.

Ulyatt, M. J., Blaxter, K. L. \& McDonald, I. (1967). Anim. Prod. 9, 463.

Van Soest, P. J. (1963). F. Ass. off. agric. Chem. 46, 829. 